\title{
Conceptual Model of Decision Making Information Used by Managers in Bulgarian Non-hospital Medical Organizations
}

\author{
Petya ANGELOVA \\ University of Economics-Varna, Varna, Bulgaria \\ p_angelova@ue-varna.bg
}

\begin{abstract}
Managerial decision making process is broadly discussed in the specialized literature. There is a great number of views and opinions about the needed prerequisites to achieve better managerial performance. No consensus on the problem has been achieved so far and the universal formula for managerial success is still a chimera. The only point upon which everyone agrees is that the information access is the milestone of an effective decision making process. That was the reason why we decided to investigate what types of information are needed by the managers in Bulgarian non-hospital medical centers to take their managerial decisions. Medical centers are specific organizations which offer specific services. They are highly regulated and this unifies to a great extent the information needs of healthcare managers. Therefore we were able to develop a conceptual model for the decision making process. The model is based on the results of a scientific research which investigates managerial practices of most successful non-hospital healthcare managers in Varna, Bulgaria. The main purpose of the conceptual model is to illustrate the relationships between the basic information needs of the healthcare managers in non-hospital medical care, their managerial decisions and conducted managerial functions. On one hand it gives an opportunity for development of more useful and complete information system for healthcare purposes. On the other hand it can serve to healthcare managers as a good start point for further development of their managerial potential in the needed directions.
\end{abstract}

Keywords: managerial decisions, information needs, healthcare management

\section{Introduction}

Healthcare system in Bulgaria received a new orientation after the beginning of the National Healthcare Reform in 2000. The new policy put the foundations of market relations in the field of medical services and thus healthcare managers had been challenged to develop new competences. There had been two reasons why healthcare organizations could not turn into typical business organizations and actually preserved some of their specific characteristics. On one hand they continued to be highly regulated by the state, and on the other they obeyed to strict social and ethical principles and norms, which prevented them from being independent in their actions and decisions. Those are the premises which make business processes in Bulgarian healthcare so specific. Economic thinking in the sector is closely related to the demands of relevant doctrine for volume and quality of medical help (Гладилов, 2005). Therefore healthcare managers must be able to combine the logic of physicians and the logic of economists in order to achieve the needed efficiency in the contemporary Bulgarian healthcare system. Exactly the combination of those two ways of thinking leads to an immence quantity of data, which should be processed by one and the same person.

In the modern world where penetration of information technologies is so rapid in almost every aspect of our lives it seems obvious that there must be an appropriate software solution for the problem. Implementation of medical software is already a fact in 
most Bulgarian healthcare organizations. European Union (EU) policy has played major role for this. A number of programs for electronic healthcare (e-health) and integrated healthcare network have been developed. Bulgarian healthcare strategy has followed those tendencies and has actively participated in the performance of all European initiatives. However all programs and actions have been focused on medical data and their transfer while business interests of healthcare organizations and managerial information needs PICBE | 458 have been ignored. Therefore the scientific investigations presented in this report are orientated towards them.

The main research object has been to identify decision making information needs in the specialized non-hospital medical care and to determine to what extent those information needs are satisfied at the current stage of development of EU e-health project.

Subject of investigation have been managers of medical centers (MC) and diagnostic-consultative centers (DCC) in the specialized non-hospital medical care. They have been chosen intentionally for three main reasons. First, MC and DCC are core elements of the healthcare system because they work with the greatest number of patients in the non-hospital care. Second, in relevance with the individual and group practices MC and DCC have much more complex activities which lead to a greater demand for managerial knowledge and skills as well as certain abilities to find and process information needed for managerial decisions. And on third place, greater number of employees in MC and DCC is a prerequisite for an active managerial behaviour, which means that there should be greater demand of quick and efficient processing of relevant managerial information.

The main hypotheses considered in the research investigate whether most successful managers in the specialized non-hospital healthcare are usually taking informed decisions and whether they realize the advantages of using contemporary ICT solutions to find and process managerial information.

Final findings served as a foundation for the development of conceptual model of decision making information used by managers in specialized non-hospital healthcare.

\section{Literature review \\ Managerial decisions}

Scientific debate about the nature of managerial decisions, types of managerial decisions and decision making process has occured as part of the management theory. Pioneers of the managerial decision making theory are three American scientists - H. Simon, J. March and H. Mintzberg, whose works serve as a start point for further scientific research in the field. After the middle of the 60s and during 70s and 80s of the XX century the number of publications and studies on the problem has grown rapidly. In most developed countries emerge scientific schools with national specifics, which systematically study decision making process (Цанов, 2005; Станчева, 2006). As a result a great number of definitions about managerial decisions and managerial decision making have been formulated (Buchanan et. al, 2006). This huge variety of view points makes it extremely difficult to choose a single definition as most appropriate, but it becomes clear that the term is closely related to managerial functions and their performance. It is result from a process of evaluation and choice of alternatives and is dependable on different factors. In this case managerial decisions have multiaspect nature, which reveals in a different way according to the situation. Therefore in our work we accept that managerial decision is a conscious action of the manager (Станчева, 2006), which aims to coordinate organizational actions and development with organizational goals and external environment (Панайотов, 1977). Managerial decision making process for us is a system of rules for acquisition and analysis 
of information, which can be applied for finding solution of certain types of problems (Grünig, 1990; Klein, 1971) and choice of way to act.

\section{Information}

Along with managerial decisions we should clarify how information is seen as a term in the present paper. Information is at one and the same time object and result from managerial work. Nowadays it is one of the most important resources for the management of any organization along with technologies and people (Haag, 2004). We live in time when knowledge gives competitive power. In the last decades we talk about "information century" and "digital age". Those tendencies occur as a result of the rapid development of information communication technologies (ICT) in every sphere of our social life. This fact leads to a new aspect in the nature of communication and closely relates it to "data". But while data are raw facts about certain phenomenon, information is processed data, put in a certain context (Haag, 2004). Even more - it should be useful for decision making purposes (Bartol, 1991). For the present work we have accepted that information is a system of data with its own meaning, created for the purposes of the managerial decision making process.

\section{Role of information systems for managerial decision making}

One of the main characteristics of ICT is that they enhance the process of data transfer and processing. According to Laudon et al. (2012, p.24) "the value of an information system to a business is, in large part, determined by the extent to which the system will lead to better managerial decisions, more efficient business processes, and higher firm profitability". Information systems directly influence decision making process by changing the ways and intensity of information delivery to key users (Laudon et.al. 2012). Computers are seen by Drucker (2002, p.172) as stimulating managers to take the right managerial decisions and preventing them from the wide spread practice to find the correct answers by luck or chance. The precise, timely and stable information flaw is considered to be an important factor for the effectiveness of managerial decisions (Level, 1988; Laudon et.al. 2012). Schultheis et al. (1995, p. 14) has tried to classify the positive effects of using computer systems in the management of organizations. He has devided them into enhancing efficiency, enhancing effectiveness and systems, created to sustain development. Scientific investigations (Борисов, 1998) about information needs on different managerial levels show that the best results are achieved when high level managers are most well informed. This once again shows that information sytems are of great importance for the top managers and play significant role to determine their effective behaviour during managerial decision making process.

\section{Non-hospital medical care and Bulgarian information system for healthcare management}

Scientific literature and the practice of developed countries show that use of market principles in the management of healthcare is seen not as an aim but as vehicle for better quality and effectiveness of healthcare, and healthcare services in particular, thus positively influencing the health of the whole population (Спасов, 2003). Medical profession is above all socially orientated and logically here comes the question to what extent an economic interests have anything in common with it. Experts (Давидов, 1998) point out that in healthcare industry the economic way of thinking is mainly related to medical effectiveness, as the economic approach has its place in solving issues related to the collection, distribution and efficient utilization of resources. This precisely expresses the specificity of managerial decision making in healthcare organizations of specialized 
non-hospital medical care, as the economic approach has its place in solving issues related to the collection, distribution and efficient utilizaion of resources. The managers of these healthcare organizations must be aware that every decision they make has two aspects economic and social. The opinion of a number of Bulgarian scientists (Давидов, 1994; Ковачев, 1997; Зафирова, 2001) on the need for "regulated competition" in the health services market is that it is fully justified because in the conditions of competition there are $\mathbf{P I C B E} \mid \mathbf{4 6 0}$ no mechanisms for regulating the social aspect of the activity. Whereas the profit and survival of a healthcare organization require appropriate behavior and market orientation, patients and the scope of activity, on the other hand, set up a framework that does not allow the management of a medical center to pursue primarily a financial result as a guiding goal. This dilemma echoes among healthcare management professionals forming two opposing concepts. The first one says it is necessary to seek the maximum health effect of each lev invested in medical services and the other one protects the opposite view that a physician is obliged to do everything in the name of patients regardless of the costs (Давидов, 1998).

Another important factor is the successful exchange of information between participants in the healthcare system. Medical centers are obligated to deliver information to certain participants in the healthcare system whose role is to perform control functions for their activities. In this way healthcare organizations become part of a specific information network. Today, the need for a unified information system for the healthcare needs in Bulgaria is clearly realized and the Ministry of Health has already been working on the project to create one. A number of companies have developed and offered specialized software for doctors working in the field of non-hospital medical care. Each system is licensed by the National Health Insurance Fund (NHIF) by checking if it meets predetermined criteria and standards. Its purpose is mainly to collect, process, store and retrieve medical information and documentation for NHIF purposes. This makes existing systems not so perfect in terms of providing information provision of management. Healthcare managers' insufficient interest in the information needs is also clearly noticed if we revise the Conceptual Model of Health Information in Bulgaria (2004). Although at first glance health information is not directly related to the activity of the senior management of a medical center, this is not quite the case. Proper planning of activities and resource needs, as well as the organization of examinations, strongly depends on what information the management unit has at its disposition.

\section{Methodology}

The used research methodology is based on the Delphi method, which, after coordination with prominent specialists in the field of statistics and health management has been modified to meet the research needs and site specificities. The study was carried out in two parts using two questionnaires. For the first part of the expert consultation the participants were selected by forming a nested sample in Varna District. A total of 59 (approximately $80 \%$ of the total) MC and DCC managers within the territory of the region were selected by simple random selection and asked to give their informed opinion and assessments. 50 of them agreed to participate in the consultation. It took the form of a semi-structured interview. We conducted it personally with each of the participants by first asking them to answer questions from the questionnaire and then to explain why they think that way.

The second part of the expert consultation ran similar to the first - as a semistructured interview, but this time participated only the managers of those medical centers that were identified (in the first part of the expert consultation) by their colleagues as the most successful in their work. The idea was to study the best practice with regard to collecting and processing information for management purposes at MCs and DCCs. 
Several considerable limitations have been placed on the resent study:

- We have assumed that a MC / DCC Manager has "sufficient information" and "good information provision" of his/her managerial decisions when all the data needed is available at the same time.

- The hypotheses related to the empirical study at this stage have been developed at a descriptive level but can be further developed in future scientificPICBE |461 developments;

- The assessment of the expert group on the "most successfully managed" MCs and DCCs is accompanied by a certain amount of subjectivism;

- The study was conducted only in the region of Varna, Bulgaria.

The most significant contribution derived from the servey is the formulated conceptual model of the managerial information in MC/DCC. Such a development, as far as we have known, has not been done so far in Bulgaria.

\section{Results and discussions}

As a result from the conducted investigation, 19 types of managerial decisions have been identified as basic for the work of the most successful managers in Varna region (see Fig. 1). They depend, on one hand, on the basic management functions (planning, organization, motivation and control) and, on the other hand are related to the specific features of different aspects of the main activity of the healthcare organizations from the non-hospital medical care. That is why we have considered that basic managerial decisions can be classified on these two attributes.

The main managerial decisions related to planning that managers of non-hospital medical care take, concern primarily patient care and in particular the financial aspects of examinations, quality and composition of the services offered by the respective center. It turns out that the most successful healthcare managers in Varna take decisions in relation to only two types of strategies: strategy for development of the services offered by the MC / DCC and strategy for improving the quality of examinations conducted in a health institution. None of these is drawn up in writing, which indicates that they have low priority for the management of the relevant health institution, although they should be leading by their significance. Most health institutions are highly dependent on the NHIF's actions and do not consider it possible and necessary to prepare long-term plans, provided that situation can be changed sharply by a small change in the Fund's provisions. There is direct planning only for income from conducted examinations, but it is rather tentative, and is usually based on the results of the previous month, without being consistent with the data on health groups and the patient contingent. The second type of planning is related to the preparation of a marketing plan. The most successful management practices at MCs and DCCs are aware of the importance of such a venture, but at the same time informally state that they do not have proper marketing plan but just compare competitors' prices.

The second core management function that is invariably present in each manager's work is the organizational one. Healthcare managers in the field of non-hospital medical care are directly involved in organizing medical records for patients. Activities that could be easily delegated. The interference of MC and DCC managers is probably due to the close relation of patient examination records with the financial provision from NHIF.

Medical centers are generally not allowed to carry out real advertising as they are a particular type of market entity. However, it is not forbidden to use information media such as boards and brochures. Observations show that their advertising actions are modest and 
Information from the external environment

\section{Marketing Information:}

- info about patients' expectations and
- info about market of healthcare services
- info about competitors
- info about target groups
- info about patients' contentment with the
healthcare services of MC/DCC

Normative information:

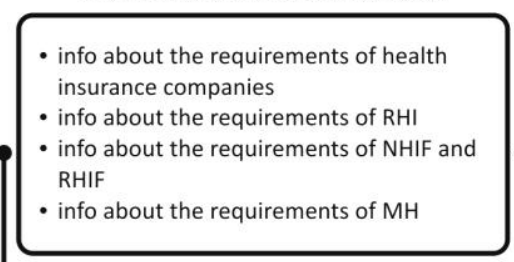

Other information from

the external environment:

- info from NSSI about the health insurance status of patients

- scientific findings in the sphere of medicine and human health

- info about contemporary healthcare methods

- other normative requirements (except the ones concerning healthcare)
९ गICBE | 462

\section{I}

$-----------1$

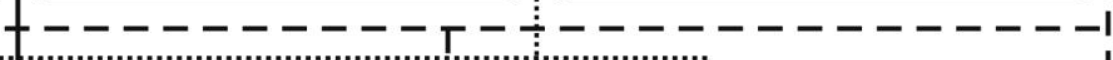

1
1
1

Planning: Organizing:

\begin{tabular}{|l}
\hline $\begin{array}{l}\text { - planning of income from } \\
\text { medical examinations } \\
\text { strategy for better } \\
\text { quality of healthcare } \\
\text { services } \\
\text { - marketing plan } \\
\text { - strategy for development } \\
\text { of healthcare services }\end{array}$ \\
\hline
\end{tabular} ORGANIZATION Controlling:

Other decisions:

- control of medical documentation about patients' examinations - control of income and costs from medical examinations

- control of payments from patients - control of health insurance of patients - control of financial operations on reception (if any)

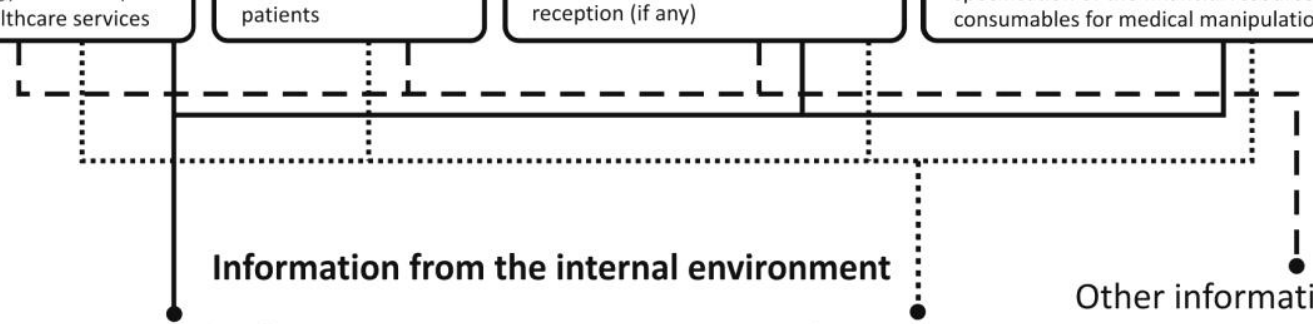

- decisions abut optimization of capacity of MC/DCC

- decisions about finding specialists for the MC/DCC

- decisions for improvement of medical methods and skills - decisions about salaries

- specification of the financial resources needed for buying technical equipment for medical manipulations

- specification of the financial resources needed for buying consumables for medical manipulations

Financial information:

- financial resources from municipality

- financial resources from $\mathrm{MH}$

- income from examinations paid by NHIF

- income from selling goods and services

- income from private examinations of patients

- income from cash payments

- income from examinations by specialist

- income by type of services

- income by type of medical tests

- income by type of examinations

- income from donations

- income from other health insurance funds

- other income

- total income from manipulations

- total income from selling other services

- information about profit

- expenses for buying medicines for the medical cabinet

- other expenses (water, electricity, etc.)

- expenses for medical materials

- expenses for salaries

- expenses for other work bonuses

- amortization expenses of the medical equipment

- current expenses for examinations

- total expenses for examinations

- transportation costs (if there is emergency service)

- fines and sanctions from NHIF

- info for profitable and non-profitable activities

- other loss
Medical information:

- information about creation

and maintenance of patients'

files

- number of ambulatory sheets against number of examinations

- number of examinations against payment for examinations

- total number of manipulations

- number of examinations by

specialist

- waiting list

- average waiting time for

examination by specialist

- info about the number of accepted patients against the

number of cured patients

- info about number of

complaints

- number of examinations in

total and by type

- number of serviced on reception patients for certain period of time

- info about duration examinations
Other information from the internal environment:

- quantity, type and price of the needed

technical equipment

- capacity of the current technical

equipment for manipulations

- current consumables - type, quantity, lifetime

- information about types of

manipulations and needed consumables

- number of popular specialists

- different specialists working in MC/DCC

- information about employment contracts

- number of people on one and the same position

- info about work schedule and real work days of doctors

- info about available working premises

- qualification and age structure of doctors

- total number of doctors

- doctors by specialty

\section{Figure 1: Conceptual Model of Decision Making Information Used by Managers in Bulgarian Non-hospital Medical Organizations}

Source: Author's own research 
often not well aimed at target patient groups but are present in all successful healthcare medical centers within the territory of Varna District.

Alarming is the fact that the main types of decisions taken by managers of nonhospital medical care do not contain decisions related to the motivational management function that each manager should perform. This means that no action is taken to promote the quality performance of work in a health organization.

Control related decisions that healthcare managers take in their current work are

PICBE | 463 the most numerous, but most of them are actually operational and may not be attributed to their duties.

Beside the implementation of decisions related to key management functions, managers at MC/DCC also deal with a number of other issues. The commitment of medical centers with the NHIF and the payment for a quantity of patients examined and the number of examinations conducted, along with the difficult financial situation of most of the patients in the country is often the reason for lack of adequate pricing and full reliance on the relations with health insurance companies. MC/DCC often do not calculate the "prime cost" of a service, but just compare with competitors' prices. On the other hand, the quality of service depends directly on the qualification of a medical center's medical team. Decisions related to the team of specialists, optimization of the capacity of a health institution and the improvement of medical techniques and approaches are of utmost importance for this indicator. However, the study shows that trainings to be organized for healthcare professionals and physicians within a health institution are carried out extremely rarely or not carried out at all.

After identifying the core groups of managerial decisions that MC and DCC managers of pre-hospital medical care take, the next step is to trace what types of information is needed for the purpose. The data used by MC/DCC managers to make managerial decisions originate from both the internal and external environment of the relevant health institution (see Figure 2).

Information coming from external environment of a health organization can be classified according to its nature into three categories: marketing information, regulatory information and other information.

Marketing information contains all the data related to processes in a micro-business environment of a health organization. It is mainly used in decision-making on MC/DCC planning, but also in solving organizational issues. This type of information is usually targeted at health services users, competitors, and the market itself. The results of the survey showed that marketing data as a whole are not available for the majority of MC and DCC managers, although they consider them necessary in taking appropriate types of managerial decisions. Consumer expectations and preferences turn out to be "unexplored territory" for healthcare managers of pre-hospital medical care. More than $50 \%$ of them share they do not have access to this type of data. The health services market is observed by $63.6 \%$ of the surveyed managers. They have the information necessary about the processes that run in it and consider it sufficient in connection with the drawing up of a marketing plan. However, the share of those who do not have the necessary data remains large. A total of $36.4 \%$ of survey participants can not procure for themselves information about the health services market. This figure diminishes when we talk about information on competitors and target patient groups. It seems like the managers of medical centers of pre-hospital medical care have made the most efforts to obtain these types of information $72.7 \%$ of them have had it and have used it, only $18.2 \%$ fail to access this type of data, even though they need them. Marketing information also serves for managerial decisions, 


\begin{tabular}{|c|c|c|c|c|c|c|c|}
\hline \multirow{2}{*}{$\begin{array}{l}\text { Basic groups } \\
\text { managerial } \\
\text { decisions }\end{array}$} & \multirow{2}{*}{ Types of information } & \multicolumn{3}{|c|}{ External Information } & \multicolumn{3}{|c|}{ Internal Information } \\
\hline & & $\begin{array}{c}\text { Marketing } \\
\text { information }\end{array}$ & $\begin{array}{c}\text { Normative } \\
\text { information }\end{array}$ & $\begin{array}{c}\text { Other } \\
\text { external } \\
\text { information }\end{array}$ & $\begin{array}{c}\text { Financial } \\
\text { information }\end{array}$ & $\begin{array}{c}\text { Medical } \\
\text { information }\end{array}$ & $\begin{array}{c}\text { Other } \\
\text { internal } \\
\text { information }\end{array}$ \\
\hline \multirow{4}{*}{$\begin{array}{l}\text { Planning } \\
\text { decisions }\end{array}$} & Planning of income from medical examinations & $\mathrm{x}$ & $\mathrm{x}$ & $\mathrm{x}$ & $\mathrm{x}$ & $\mathrm{x}$ & $\mathrm{x}$ \\
\hline & Strategy for better quality of healthcare services & $\mathrm{x}$ & $\mathrm{x}$ & $\mathrm{x}$ & $x$ & $\mathrm{x}$ & $\mathrm{x}$ \\
\hline & Marketing plan & $x$ & $\mathrm{x}$ & $x$ & $\mathrm{x}$ & $x$ & $x$ \\
\hline & Strategy for development of healthcare services & $\mathrm{x}$ & $\mathrm{x}$ & $\mathrm{x}$ & $\mathrm{x}$ & $\mathrm{x}$ & $\mathrm{x}$ \\
\hline \multirow{3}{*}{$\begin{array}{l}\text { Organizing } \\
\text { decisions }\end{array}$} & Organization of medical examinations & $\mathrm{x}$ & $\mathrm{x}$ & & & $\mathrm{x}$ & $\mathrm{x}$ \\
\hline & Organization of advertisement activities for MC/DCC & $\mathrm{x}$ & $x$ & & & $\mathrm{x}$ & $x$ \\
\hline & Organization of medical documentation for patients & $\mathrm{x}$ & $x$ & & & $\mathrm{x}$ & $x$ \\
\hline \multirow{5}{*}{$\begin{array}{l}\text { Controlling } \\
\text { decisions }\end{array}$} & $\begin{array}{l}\text { Control of medical documentation about patients' } \\
\text { examinations }\end{array}$ & & $\mathrm{x}$ & $\mathrm{x}$ & & $\mathrm{x}$ & $\mathrm{x}$ \\
\hline & \begin{tabular}{|l|} 
Control of income and costs from medical \\
examinations
\end{tabular} & & $\mathrm{x}$ & $\mathrm{x}$ & $\mathrm{x}$ & $\mathrm{x}$ & $\mathrm{x}$ \\
\hline & Control of payments from patients & & $\mathrm{x}$ & $x$ & $x$ & $\mathrm{x}$ & $x$ \\
\hline & Control of healthinsurance of patients & & $\mathrm{x}$ & $\mathrm{x}$ & & $\mathrm{x}$ & $\mathrm{x}$ \\
\hline & Control on financial operations on reception (if any) & & $\mathrm{x}$ & $\mathrm{x}$ & $\mathrm{x}$ & $\mathrm{x}$ & $\mathrm{x}$ \\
\hline \multirow{7}{*}{$\begin{array}{l}\text { Other } \\
\text { decisions }\end{array}$} & Decisions about pricing & & $\mathrm{x}$ & $\mathrm{x}$ & $\mathrm{x}$ & $x$ & $x$ \\
\hline & Decisions about optimization of capacity of MC/DCC & & $x$ & $\mathrm{x}$ & $x$ & $\mathrm{x}$ & $x$ \\
\hline & Decisions about finding specialists for MC/DCC & & $\mathrm{x}$ & $\mathrm{x}$ & $\mathrm{x}$ & $\mathrm{x}$ & $\mathrm{x}$ \\
\hline & $\begin{array}{l}\text { Decisions for improvement of medical methods and } \\
\text { skills }\end{array}$ & & $\mathrm{x}$ & $\mathrm{x}$ & $\mathrm{x}$ & $\mathrm{x}$ & $\mathrm{x}$ \\
\hline & Decisions about salaries & & $x$ & $\mathrm{x}$ & $x$ & $\mathrm{x}$ & $\mathrm{x}$ \\
\hline & $\begin{array}{l}\text { Specification of the financial resources needed for } \\
\text { buying technical equipment for medical manipulations }\end{array}$ & & $x$ & $x$ & $x$ & $x$ & $x$ \\
\hline & \begin{tabular}{|l|} 
Specification of the financial resources needed for \\
buying consumables for medical manipulations
\end{tabular} & & $\mathrm{x}$ & $\mathrm{x}$ & $\mathrm{x}$ & $\mathrm{x}$ & $\mathrm{x}$ \\
\hline
\end{tabular}

PICBE | 464

Figure 2: Types of information needed for taking basic groups managerial decisions

Source: Author's own research

related to the organization of advertising. A total of $72 \%$ of the surveyed experts shared they were unable to procure and did not have information about consumer expectations and preferences, although they needed it. There is a clear inconsistency in respondents' answers to the survey. Nearly $20 \%$ of them indicated this data as available when it came to preparation of a marketing plan and now declare that they do not have them available. Similar is the situation with information about target patient groups. For organization of advertising, $45.5 \%$ of the respondents claimed they did not have the data they needed, whereas, upon drawing up a marketing plan only $18.2 \%$ admitted that they needed such information but were not able to procure it.

On second place we will make a review of regulatory information. It derives from all kinds of legal and other regulations that affect the work of MC/DCC. Decisions most depending on the regulatory information are those related to the organization of the medical records for patients. Most of the managers included in the survey indicated that they had enough information available. Regulatory information related to NHI Fand RHIF is available to absolutely all MC/DCC managers who consider it necessary. This is definitely due to the important role that the compliance with the statutory requirements of the Fund plays in the financing of the activities of non-hospital healthcare organizations. The Ministry of Health $(\mathrm{MH})$ is not so effective in dissemination of its requirements and regulations. It turns out that $18.2 \%$ of respondents do not have the information they need about it or have difficulties to acquire it. In general, access to regulatory information by managers of non-hospital medical care seems to be satisfactory.

In the other information category are contained all data that come from the external environment of MC/DCC, but have no normative or marketing character. These types of information are primarily used in decision-making related to control and types of decisions indirectly related to core management functions. Some of these data serve as the 
basis for decision-making concerning the improvement of medical equipment and approaches, the control of patient health contributions and wage formation.

Apart from the influence of the external environment, in decision-making, the information coming from the health organization itself is also determining. We have classified it into three major groups: financial information, information related to medical activity and other information.

Financial information includes all monetary items of income and expense that would be useful to a manager's work in a healthcare organization. It has the strongest influence on planning related decisions, control related decisions, as well as other decisions related to the activity of a health institution. It usually comes from several basic units in a medical center - accounting, registry desk and laboratory (if any, and it is not serviced by the registry desk of the respective health institution). The categories that are least secured and in practice represent unavailable but necessary information for MC and DCC managers are only a few - current and general costs for examinations (18.2\% of the respondents), income from examinations (18.2\%), other losses (18.2\%). Unlike information coming externally, internal information is far easier to acquire and its availability depends only on the organizational skills and management style of the healthcare manager. The process is further facilitated by the already integrated information systems that service both financial and accounting operations of the medical center and the documentary processing of the conducted examinations. This is the only type of data that are being actively monitored by all managers of MC/DCC.

Information related to medical activity can not boast the same, although high information provision is noticed here too. Data used for related managerial decisions is usually concerning direct medical work and the results thereof. All types of medical activity related information are actively used in taking core groups of managerial decisions, making them exceptionally important to MC and DCC managers.

Simultaneously with the data concerning the main activity of a health institution, other information coming from the internal environment circulates in it. That information most often refers to equipment, facilities and staff. It is often not of key importance, but plays an important role in the normal functioning of a medical center, and in this sense is used for making all types of basic decisions.

It is evident that normative information coming from the external environment and medical and other information coming from the internal environment are important for making all kinds of basic managerial decisions. In this sense, the needs for data in these three directions appear to be vital for the management activity of MC/DCC. That is why healthcare managers should put an emphasis on this types of information in order to take informed decisions.

\section{Conclusion}

The current conceptual model introduces the main types of managerial decisions, the types of information normally associated with them, and the sources of its procurement. In this way it allows for any gaps to be found in these three directions at MC/DCC level Thus, the quality of the managerial decisions could be improved by outlining the directions in which it is necessary to procure data for better information provision of the management process. The model can be used both in theory and in practice. It constitutes a good complement to the Conceptual Model of Healthcare Information in Bulgaria (2004) regarding the relation of medical information to the management of MCs and DCCs of specialized non-hospital care. In practice the model can serve as a base platform for creating specialized software for the needs of the healthcare management. 


\section{References}

Bartol, K., D. C. Martin (1991) Management, New York: McGraw - Hill

Борисов, В., Зл. Глутникова и Ц. Воденичаров (1998) Ново обществено здравеопазване, София: Акваграфикс (Borisov, V., Zl. Glutnikova, Ts.

Vodenicharov (1998) New social healthcare, Sofia: Aquagraphix)

Buchanan, Leigh \& Andrew O'Connell (2006, January) Brief history of decision making, Harvard Business Review, Retrieved from https://hbr.org/2006/01/a-brief-history-of-decision-making

Коен, Ст., У. Еймике (2000) Новият ефективен мениджър в държавния сектор, София: ЛИК (Cohen, St., W. Eimicke (2000) The new effective manager in the public sector, Sofia: LIK)

Conceptual model of healthcare information in Bulgaria (2004), publication on project: Reform in Healthcare Sector, Section Health-information standards Documentation and classification, developed by National Organization of Social Medicine, Informatics and Healthcare Management, in BG language, Retrieved from http://www.nchi.government.bg/ZIS.html

Давидов, Б. (1994) Ситуацията: възможните подходи за изход от нея, Бюлетин за икономическа информация в здравеопазването, НЦЗИ, бр. 3 (Davidov, B. (1994) The situation: possible ways out, News Release for Economic Information in Healthcare, NCHI in MH, vol. 3)

Давидов, Б. (1998) Здравната реформа в България, II част, МЗ, Европейски съюз, програма PHARE, София: Македония Прес (Davidov, B. (1998) Healthcare reform in Bulgaria, II part, MH, EU, PHARE program, Sofia: Macedonia Press)

Дракър, П.(2002) Ефективният ръководител, София: Класика и Стил (Drucker, P. (2002) The effective executive, Sofia: Classics and Style)

Гладилов, Ст. (2005) Икономическият начин на мислене в здравеопазването, Здравен мениджмънт, 5 (2), стр. 3-4 (Gladilov, St. (2005) Economic Way of Thinking in Healthcare, Healthcare Management, 5 (2), p. 3-4)

Grünig, R. (1990) Verfahren zur Überprüfung und Verbesserung von Planungskonzepten, Habilitation, Haupt Bern

Haag, Stephen, Maeve Cummings \& Donald J. McCubbrey (2004), Management information systems: for the Information Age, $4^{\text {th }}$ Ed., London : McGraw-Hill Irwin

Klein, Heinz-Karl (1971) Heuristische Entscheid Modelle: Neue Techniken des Programmierens und Entscheidens fur das Management, Wiesbaden: Springer

Ковачев, А. (1997) Бизнес среда, В. Търново:Абагар (Kovachev, А. (1997), Business Environment, V. Turnovo: Abagar)

Laudon, K. C., J. P. Laudon (2012) Management Information Systems - Managing the Digital Firm, New York : Macmillian Publishing Company

Level, A. D., W. P. Galle (1988), Managerial communications, Homewood: Irwin

Schultheis, R, M. Sumner (1995) Management information systems: The manager's view, 3d ed, Richard D. Irwin Inc.

Панайотов, Д. (1977) Принос към теорията на стопанското управление, Свищов: Д. Ценов (Panayotov, D. (1977) Contribution to theory of management, Svishtov: D. Tsenov)

Спасов, К., (2003) Социален мениджмънт, София: АПИС (Spasov, K. (2003) Social Management, Sofia: APIS)

Станчева, А. (2006) Основи на управлението, Варна: Стено (Stancheva, А. (2006) Foundations of management, Varna: Steno) 
Цанов, И. (2005) Проблемът за вземане на управленско решение в конфликтни ситуации, Икономически алтернативи, София: УНСС, бр.2, източник:

http://alternativi.unwe.bg/alternativi/index.php?nid=2\&hid=29 (Tsanov, I. (2005) The Problem with Taking Managerial Decision in Conflict Situation, Economic Alternatives, Sofia: University of National and World Economy, Issue 2, Retrieved from http://alternativi.unwe.bg/alternativi/index.php?nid=2\&hid=2)

Зафирова, Ц. (2001) Избор на стратегия в управлението на болниците, Варна: ГорексПрес (Zafirova, Tsveta (2001), Choice of a strategy in management of hospitals, Varna: GorexPress) 